\title{
Does physical fitness and parenting transformational style predict happiness and wellbeing and distress in adolescents? ¿La condición física y el estilo parental transformacional predicen la felicidad, el bienestar y angustia psicológica de los adolescentes? \\ *Alberto Ruiz-Ariza, *Manuel J. De la Torre-Cruz, **Kaija Appelqvist-Schmidlechner, **Nina Tamminen, *Emilio J. Martínez-López \\ *Universidad de Jaén (España), ${ }^{* *}$ National Institute for Health and Welfare (Helsinki, Finlandia)
}

\begin{abstract}
There is a growing interest on the relationships between family functioning and behaviors that promote physical and psychological well-being in children and adolescents. The aim of the study was to assess the association of parenting transformational style with happiness, wellbeing and distress in adolescents, beyond of physical fitness influence, and independently of age and body mass index. Data were gathered among 868 Spanish schoolchildren aged 12-16 years $(\mathrm{M}=14.07, \mathrm{SD}=1.24)$ with a self-administered questionnaire and conducting physical fitness tests. The findings showed that age and the perception of a maternal and paternal transformational style predicted happiness, wellbeing and distress in adolescent girls. In boys, only the parental transformational style acted as a significant predictor, independently of fitness level. Muscular strength contributed to explain the wellbeing in adolescent girls independently of transformational style; however, it did not happen in speed-agility and cardiorespiratory capacity. Findings suggest that promotion of parenting transformational style is beneficial to the psychological wellbeing, above all in younger adolescents. In girls, promotion of higher muscular strength could contribute to improve happiness and wellbeing independently of parental transformational styles.
\end{abstract}

Key words: transformational parenting; adolescents; fitness; psychological well-being.

\begin{abstract}
Resumen: Hay un creciente interés en el examen de la relación entre funcionamiento familiar y conductas que promueven el bienestar físico y psicológico de niños y adolescentes. El objetivo de este estudio fue evaluar la asociación entre el estilo parental transformacional y la felicidad, bienestar y angustia psicológica, más allá de la posible influencia de la condición física, edad e índice de masa corporal de un grupo de adolescentes. Se obtuvieron valores de 868 jóvenes españoles con edades comprendidas entre los 12-16 años de edad (M=14.07, $\mathrm{SD}=1.24$ ) en medidas de autoinforme y pruebas de condición física. Los resultados mostraron que la edad y la percepción de un estilo materno y paterno transformacional predijeron la felicidad, bienestar y angustia psicológica en las chicas adolescentes. En los chicos, solo el estilo transformacional parental actuó como un predictor significativo, más allá de la condición física. La fuerza muscular contribuyó a explicar el bienestar de las chicas adolescentes de forma independiente al estilo transformacional, algo que no ocurrió con la velocidad y la capacidad cardiorrespiratoria. Los resultados sugieren que la promoción de un estilo parental transformacional es beneficiosa para el bienestar psicológico, especialmente, en los jóvenes adolescentes. En las chicas, la promoción de una mayor fuerza muscular podría contribuir a la mejora de la felicidad y el bienestar, de un modo independiente, al estilo parental transformacional.

Palabras clave: estilo parental transformacional; adolescentes; condición física; bienestar psicológico.
\end{abstract}

\section{Introduction}

Promoting physical activity (PA) practice and improving physical fitness in children and adolescents is a priority objective in public health systems (Smith et al., 2014). Nevertheless, during the last twenty years, there has been a progressive decrease in the practice of PA and, therefore, lower levels of physical fitness in youth (Boros, Fontana \& Mack, 2017). Current research results suggest that physical fitness levels are positively associated with physical and psychological health in youth population (Ho, Louie, Chow, Wong \& Ip, 2015). For instance, studies by MacMahon et al. (2017), or Smith et al. (2014) revealed that a higher level of physical fitness is associated with lower incidence of anxietydepressive symptoms and greater subjective well-being in the adolescent population. Jiménez-Moral, Zagalaz-Sánchez, Molero, Pulido-Martos and Ruiz (2013), concluded that cardiorespiratory capacity was positively associated with happiness and satisfaction with life. Likewise, Bonhauser et al. (2005), observed an increase in self-esteem and a decrease in anxiety level of adolescents participating in a school PA programme aimed to improve the physical fitness.

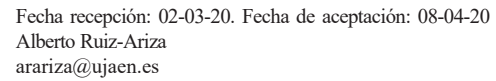

On the other hand, along the last two decades, there has been a growing interest in the analysis of the relationships between family functioning and behaviors that promote physical and psychological well-being in children and adolescents (Huffman, Wilson, Van Horn \& Pate, 2018; Lim, You \& Ha, 2015). Beyond traditional styles of parental socialization (democratic, permissive, negligent and authoritarian), the interest by the so-called parenting transformational style has appeared in the last decade (Morton et al., 2011; Morton, Wilson, Perlmutter \& Beauchamp, 2012; Popper \& Mayseless, 2003). Transformational leaders aim to empower and inspire others, transcend one's own self-interests and give others the confidence to achieve higher levels of functioning (Bourne et al., 2015). Based on the study of Popper and Mayseless (2003), Álvarez, Castillo and Moreno-Pellicer (2019), establish an analogy between leaders and parents who carry out transformational behaviors, identifying a series of traits common to each other; they are sensitive and attend to the needs of employees and children, they usually accept their ideas, they do not make judgments of value in a hasty way, establish rules and limits that can be modified and act as models with which to identify positively. Parenting transformational style is characterized by the provision of support, encouragement and positive affection towards the children, the transmission of the idea of respecting others, 
along with the establishment of appropriate norms of conduct that, if broken, they are not counteracted by coercive disciplinary measures (Morton et al., 2011; Morton et al., 2012).

Carrying out a transformational leadership in the family, teaching and sporting context (Álvarez, Castillo, MolinaGarcía \& Balagué, 2016; Arthur, Woodman, Ong, Hardy \& Ntoumanis, 2011; Verma, Eklund, Arthur, Howle \& Gibson, 2019), is positively associated with the maintenance of a diet and PA practice performed in free time situations (Morton et al., 2012), self-regulating efficacy for PA, adherence to healthy eating and the satisfaction with life (Morton et al., 2011), as well as a more positive physical self-concept (De la TorreCruz, Ruiz-Ariza, López-Serrano \& Martínez-López, 2018). Recently, Álvarez et al (2019) have examined the relationship between transformational parenting, autonomy support, and burnout in adolescents enrolled in different football clubs. The young players who attributed to their parents greater behaviors typical of the transformational style perceived in them a greater degree of support for autonomy and indicated that they suffered less burnout. Besides, only for mothers, the relationship between transformational behaviors and youth burnout was completely mediated by the level of autonomy support attributed to them. For their part, Stenling and Tafvelin (2014), found that the relationship between the coach's transformational leadership and well-being in adolescent athletes, was mediated by the subjective perception of the satisfaction of psychological needs of young people. In a similar way, Bourne et al. (2015) and Verma et al. (2019) showed that PA identity, PA self-presentational thoughts and self-efficacy mediated the relationship between girls' perceptions of transformational teaching in physical education teachers and moderate-to-vigorous PA.

As suggested in the preceding lines, physical fitness level and transformational parental style seem to be associated with the physical and psychological well-being of young people (Álvarez et al., 2019; Stenling \& Tafvelin, 2014). However, it is not known to what extent both variables can contribute jointly to the increase in subjective happiness, mental well-being and reduction of psychological distress. Therefore, this study aimed to examine the extent to which the attribution of a transformational style in mothers and fathers could increase the percentage of variance explained in subjective happiness and psychological wellbeing and distress, beyond that reported by physical fitness, after controlling variables such as age, sex, and BMI of adolescents.

\section{Method}

\section{Participants}

A total of 868 secondary school students (459 girls, 52.9\%), aged between 12 and 16 years $(M=14.07, S D=1.24)$, from 12 educational centers located in a province of Andalusian (Spain), took part in this study. The average weight was 58.64 kilograms $(S D=13.81)$, and the average height was 1.63 meters $(S D=.84)$. Both values were used to calculate the body max index (BMI) according to the formula established by Quetelet $\left[\mathrm{BMI}=\right.$ weight $(\mathrm{kg}) /$ height $\left.\left(\mathrm{m}^{2}\right)\right]$. The mean of $\mathrm{BMI}$ was 21.86 $(S D=4.09)$. When the anthropometric varia- bles were examined according to sex, results revealed favorable differences for the boys in body weight $(M=61.98 \mathrm{vs}$ $M=55.67 \mathrm{~kg})$ and height $(M=1.66 \mathrm{vs} M=1.60 \mathrm{~m})$, but not in BMI $\left(M=22.25\right.$ vs $M=21.79 \mathrm{k} / \mathrm{m}^{2}$ for boys and girls respectively).

\section{Instruments}

Anthropometric and physical fitness measures

Participants' weight and height were recorded using a digital scale ASIMED ${ }^{\circledR}$ model Elegant type B - class III, and a portable $\mathrm{SECA}^{\circledR} 214$, respectively. The measurements were taken with the participant barefoot and dressed in light clothing. ALPHA-fitness battery was use to assess physical fitness. The procedure and reliability was shown by Ruiz et al. (2011). The fitness tests used were standing long jump test, to assess the explosive strength of the lower limbs, the 20-meter shuttle-run test (Leger, Mercier, Gadour \& Lambert, 1988) to assess the cardiorespiratory capacity, and the $4 \times 10$ $m$ speed-agility test, to assess the velocity of displacement. In both jumping and speed tests, the best result was recorded after two attempts.

\section{Self-report measures}

Transformational Parenting Questionnaire «TPQ» (Morton et al., 2011).

The questionnaire is composed of 16 items that assess the extent to which young people perceive a transformational educational style in their parents through a set of behaviors. The set of items is preceded by the introductory phrase « $M y$ father/mother/legal guardian,...,», followed by different statements (for example, «Trust that I can achieve the things that I propose»). Responses were issued along a six-point scale ranging from 1 (completely disagree) to 6 (completely in agreement). Although the scale was conceived to explore each dimension that make up the transformational style (idealized influence, inspiring motivation, intellectual stimulation and personal consideration), Morton et al. (2011), provided evidence that the construct was more parsimonious and operational when all items were combined into one dimension (transformational style). Recently, Álvarez et al. (2019), have carried out a Spanish adaptation of this questionnaire. After obtaining the responses of a sample of adolescents and carrying out a confirmatory factor analysis, they concluded that the four dimensions mentioned contributed to the existence of a single higher-order factor that could be called as transformational parenting style. Thus, in this study an overall score was calculated for each parent and its range was between 16 and 86 points. A higher value corresponded to greater transformational style. The reliability indexes obtained and calculated through the Cronbach alpha, were .93 and .95 (mothers and fathers, respectively).

Subjective happiness (Lyubomirsky \& Lepper, 1999).

Happiness was assessed with the Subjective Happiness Scale (Lyubomirsky \& Lepper, 1999). Participants answered four questions related to subjective happiness - i.e. Many people are generally very happy, enjoy life regardless of what happens and make the most of everything. To what extent do you identify with these people?-. The variable «happiness» corresponds to the mean of the direct scores of the items. The scale of response ranges from 1 to $7(1=$ 
lower happiness, $7=$ higher happiness). The reliability index of the only dimension of this questionnaire obtained by Cronbach alpha was .72. 2000).

Psychological well-being and distress (Heubeck \& Neill,

Psychological well-being and distress were assessed through the adaptation by Heubeck and Neill (2000) of the original questionnaire General Well-Being (Veit \& Ware, 1983). Participants answered 20 questions, of which 10 items assess psychological well-being -i.e. Have you really enjoyed things? - and others 10 assess distress - i.e. Have you felt low or very low in spirit?- - The response scale has 6 alternatives $(1=$ never, $2=$ rarely, $3=$ sometimes, $4=$ most of the time, $5=$ often, and $6=$ all of time). The reliability indexes obtained in each dimensions by Cronbach alpha were: wellbeing $=.81$ and distress $=.85$.

\section{Procedure}

The data were collected during spring 2015, during Physical Education (PE) classes. Researchers applied the questionnaires helped by PE teachers. Physical fitness test were performed following the protocol by Ruiz et al. (2011). Participation was voluntary and unrewarded. The study obtained reported consent from parents and it was approved by the Bioethics Committee of the University of XXX (omitted for anonymity). The design complies with the Spanish regulations for clinical research in humans (Law 14/2007, $3^{\text {rd }}$ July, of Biomedical Research), and with the principles of the Declaration of Helsinki (2013 version, Brazil).

\section{Data analysis}

To examine the possible differences between girls and boys, the $t$-test for independent samples was used. Pearson correlation analysis was carried out to know the relationship between the variables of the study, as well as several multiple hierarchical regression analyses to predict the achieved scores on subjective happiness, psychological well-being and distress. In the last analysis, predictor variables were incorporated along three blocks: the first one examined the effect of the personal variables (age and BMI typified according to the participant's sex), the second one included physical fitness test results (speed-agility, standing long jump test, and cardiorespiratory capacity). Finally, in the third block, the transformational style perceived in both, mothers and fathers, was added to the above variables. The probability value for all tests was set at $\mathrm{p}<.05$. The analyses were performed using the SPSS statistical program (v. 20.0). Given that statistically significant differences were observed in the dependent variables according to the sex of the participant, correlation and regression analysis (table 2 and 3), were performed separately for girls and boys.

\section{Results}

\section{Descriptive analysis}

The mean values, standard deviations, contrast statistic value, significance of the different measures and Cohen's d value that reports the observed effect size between the mean differences, according to the sex of the participant, are shown in Table 1. Boys show higher scores in weight, height, speedagility, standing long jump, cardiorespiratory capacity, happiness, wellbeing and lower distress than girls. In addition, the boys attributed to the father figure greater behaviors typical of a transformational style than indicated by the girls. The observed effect size for all the measures of physical fitness was large (minimum value of $d$ of 1.06 for the variable of cardiorespiratory fitness), while in the case of the measures of subjective well-being it was small (maximum value of $d$ of .33 for the wellbeing).

Table 1.

Mean, standard deviation (in brackets), $t$ value of independent measures and statistical significance of the different measures according to sex.

\begin{tabular}{|c|c|c|c|c|c|c|}
\hline & $\begin{array}{c}\text { Overall } \\
(\mathrm{n}=868)\end{array}$ & $\begin{array}{c}\text { Girls } \\
(\mathrm{n}=459)\end{array}$ & $\begin{array}{c}\text { Boys } \\
(\mathrm{n}=409)\end{array}$ & $t_{(866)}$ & $p$ & $d$ \\
\hline Weight (kilos) & $\begin{array}{c}58.64 \\
(13.81)\end{array}$ & $\begin{array}{c}55.67 \\
(11.56)\end{array}$ & $\begin{array}{c}61.98 \\
(15.30)\end{array}$ & -6.79 & $<.001$ & .50 \\
\hline Height (metres) & $\begin{array}{l}1.63 \\
(.08)\end{array}$ & $\begin{array}{l}1.59 \\
(.06)\end{array}$ & $\begin{array}{l}1.66 \\
(.09)\end{array}$ & -12.38 & $<.001$ & .78 \\
\hline BMI & $\begin{array}{l}22.00 \\
(4.25) \\
\end{array}$ & $\begin{array}{l}21.79 \\
(4.03) \\
\end{array}$ & $\begin{array}{l}22.25 \\
(4.48) \\
\end{array}$ & -1.60 & n.s. & - \\
\hline Time 4 × 10 (seconds) & $\begin{array}{l}12.37 \\
(1.28) \\
\end{array}$ & $\begin{array}{l}12.98 \\
(1.11) \\
\end{array}$ & $\begin{array}{l}11.69 \\
(1.10) \\
\end{array}$ & 17.09 & $<.001$ & 1.14 \\
\hline C-N (paliers) & $\begin{array}{c}4.90 \\
(2.40)\end{array}$ & $\begin{array}{c}3.84 \\
(1.72) \\
\end{array}$ & $\begin{array}{c}6.10 \\
(2.49) \\
\end{array}$ & -15.37 & $<.001$ & 1.06 \\
\hline Standing long jump $(\mathrm{cm})$. & $\begin{array}{l}148.43 \\
(29.67)\end{array}$ & $\begin{array}{l}133.42 \\
(21.28)\end{array}$ & $\begin{array}{l}165.24 \\
(28.77)\end{array}$ & -18.35 & $<.001$ & 1.25 \\
\hline Transformational (mother) & $\begin{array}{l}5.30 \\
(.64) \\
\end{array}$ & $\begin{array}{l}5.30 \\
(.67) \\
\end{array}$ & $\begin{array}{l}5.31 \\
(.62) \\
\end{array}$ & -.25 & n.s. & - \\
\hline Transformational (father) & $\begin{array}{l}5.12 \\
(.86)\end{array}$ & $\begin{array}{l}5.03 \\
(.96)\end{array}$ & $\begin{array}{l}5.19 \\
(.72)\end{array}$ & -2.67 & $<.01$ & .19 \\
\hline Happiness & $\begin{array}{c}5.32 \\
(1.09)\end{array}$ & $\begin{array}{c}5.20 \\
(1.15)\end{array}$ & $\begin{array}{c}5.45 \\
(1.00)\end{array}$ & -3.39 & $<.005$ & .23 \\
\hline Well-being & $\begin{array}{l}4.32 \\
(.78)\end{array}$ & $\begin{array}{l}4.20 \\
(.82)\end{array}$ & $\begin{array}{l}4.45 \\
(.70)\end{array}$ & -4.93 & $<.001$ & .33 \\
\hline Distress & $\begin{array}{l}2.61 \\
(.81)\end{array}$ & $\begin{array}{l}2.72 \\
(.85)\end{array}$ & $\begin{array}{l}2.48 \\
(.76)\end{array}$ & 4.50 & $<.001$ & .30 \\
\hline
\end{tabular}

\section{Correlation analysis}

A similar pattern of results was observed in girls and boys. All the measures of physical fitness were related to each other in a negative way (with the exception of those observed between BMI and time invested in the speed-agility test, as well as between paliers in the Course-Navette and standing long jump test that did it in a positive way). Furthermore, all correlations between transformational parenting style and measures of well-being (happiness, distress, and well-being) were found to be statistically significant (negative for transformational parenting and distress and positive for transformational parenting, happiness, and well-being). The values are shown in table number 2 .

Table 2.

Bivariate correlations between variables. Upper diagonal (girls) and lower diagonal (boys).

\begin{tabular}{|c|c|c|c|c|c|c|c|c|c|}
\hline & 1 & 2 & 3 & 4 & 5 & 6 & 7 & 8 & 9 \\
\hline 3MI & & $251^{* *}$ & $-.359^{* *}$ & $-.364^{* *}$ & -.04 & -.07 & -.09 & 03 & -.03 \\
\hline Time 4 x 10 (seconds) & $.216^{* *}$ & & $-.400^{* *}$ & $-.588^{* *}$ & -.06 & -.07 & -.08 & .01 & .01 \\
\hline Course-Navette (number of paliers) & $-399^{* *}$ & $-.512^{* *}$ & & $.525^{* *}$ & -.01 & 0.08 & 0.08 & -0.03 & 0.02 \\
\hline Standing long jump (metres) & $-.261^{1 * *}$ & $-.649^{* *}$ & $.569^{* *}$ & & .000 & $.092^{*}$ & $.109^{*}$ & .004 & .057 \\
\hline Transformational style (mothers) & -.017 & .010 & -.019 & -.060 & & $.562^{* *}$ & $.402^{* *}$ & $-.421^{* *}$ & $.479^{* *}$ \\
\hline ransformational style (fathers) & -.072 & -.056 & -.008 & .007 & $.686^{* *}$ & & $.337^{* *}$ & $-.382^{* *}$ & $.422^{* *}$ \\
\hline Happiness & -.084 & -.047 & .064 & .088 & $.364^{* *}$ & $.265^{* *}$ & & $-.649^{* *}$ & $.688^{* 3}$ \\
\hline Distress & .040 & .011 & .001 & -.037 & $-337^{* *}$ & $-323^{* *}$ & $-.580^{* *}$ & & $-838^{* *}$ \\
\hline Well-being & $-.100^{*}$ & -.022 & .048 & .009 & $.375^{* *}$ & $.367^{* *}$ & $.616^{* *}$ & $-.769^{* *}$ & \\
\hline
\end{tabular}

\section{Multiple hierarchical regression analysis}

In girls, the final model including the three blocks of predictor variables reported the $19.1 \%$ of the variance in happiness $\left[R=.437, R^{2}=.191 ; F(7,451)=15.22, p<.001\right]$. The maternal $(\beta=.32, p<.001)$ and paternal $(ß=.14, p<.01)$ transformational style were significant predictors of happiness. Regarding to wellbeing, age $(\beta=-.15, p<.001)$, standing long jump $(\beta=.12, p<.05)$ as well as maternal $(\beta=$ $.36, p<.001)$ and parental transformational style $(\beta=.19, p<$ $.001)$ reported the $29.4 \%$ of observed variance $\left[R=.543, R^{2}=\right.$ 
the parenting transformational style in both sex and the muscular strength in girls, from educational, family and social context, to improve psychological health during the adolescence.

Our results of negative association between age and psychological wellbeing are in line with Moreira et al. (2015). In this study, secondary school adolescents showed higher scores in satisfaction with life, quality of life, and positive affect compared with older baccalaureate students. It is possible that the increasing assumption of responsibilities as well as the greater demands associated with the proximity of adulthood (academic, labor and affective decision making) can contribute to the marked loss of quality of life and subjective well-being (Kim, 2016; Moreira et al., 2015).

When the emotional state of adolescents was compared taking into account the extreme levels of congruent transformational parenting in mothers and fathers, as well as the perception of inconsistent parenting, it was observed that the youth who attributed a high and consistent transformational parenting to their parents reported a higher subjective happiness, well-being and less degree of distress in relation to the other two groups. This finding partially agrees with that obtained by Álvarez et al. (2019) in whose study the attribution of an incongruent transformational parenting (high in one parent, but low in the other) did not produce differences in the burnout of young players in relation to the peers who reported a consistent parenting (with high or low). Perhaps the small number of adolescents included in the incongruent group of our study $(n=20)$ is responsible for these differences.

The present study showed that perceived transformational parental style in mothers and fathers is positively associated with subjective happiness and psychological well-being, as well as in a negative way with the distress in all participants. This result is consistent with the recently obtained by Álvarez et al. (2019). In his study with adolescents belonging to different football clubs, it was found that the attribution of a higher level of transformational parenting, in any of the parents, negatively predicted the burnout rate of young football players. In addition, the support for autonomy that the children perceived in their mothers mediated the relationship described in the transformational style and burnout. Similarly, Stenling and Tafvelin (2014) showed that transformational coaches have a positive influence on well-being of athletes through the satisfaction of the basic needs of autonomy, competence and belonging.

The examination of potential predictors of happiness, wellbeing and distress, has revealed similarities and differences in girls and boys. Greater perception of maternal and paternal transformational style predicted positively wellbeing, and negatively distress in participants of both sexes. In addition, for females, age became a negative and statistically significant predictor of psychological well-being. Finally, of all measures of physical fitness included, only explosive strength contributed to the psychological wellbeing in girls. These findings are contrary to expectations and do not confirm those obtained in previous research suggesting that physical fitness is a positive and significant predictor of psychological well-being and psychological health in adolescents (Ho et al., 2015, Jiménez-Moral et al., 2013, McMahon et al., 2017), or even that the improvement in the physical fitness induced through participation in a PA program increases this well-being (Bonhauser et al., 2005).

A possible reasoning of the above could be in the criteria measure used. Unlike the study by Jiménez-Moral et al. (2013), the previous research used self-concept, self-esteem, reduction of anxious and depressive symptomatology or satisfaction with life as criteria measures. Although all these variables are indicators of happiness, wellbeing and distress, they may have specific characteristics whose respective increase and decrease depend more on social or relational factors than on physical or physiological factors. In future studies, more complex models including also social and relational factors are needed in order to investigate this phenomenon.

Based on the last annotation, the results suggest that the perception of a maternal and paternal transformational style contributes to the increase of the variance explained in practically all criteria measures. This result is in line with findings obtained by Morton et al. (2011), Stenling and Tafvelin (2014) and Skakon Nielsen Borg and Guzman (2010) whose perception of transformational leadership is restricted to the family, sport and business contexts. As Stenling and Tafvelin (2014) point out, the mechanisms of a transformational leader to favour wellbeing are not well understood. However, it has been considered the possibility of the leader transfering positive emotions to his followers through a process of modeling or emotional contagion (Bono \& Ilies, 2006). Álvarez et al. (2019) suggest that the open communication with children, the proposal of rules after considering the children points of view, as well as the mutual respect that takes place in the parent-child interaction, all of them distinctive behaviors of transformational parenting, serve as an inspiring role model for young people, thus promoting a feeling of well-being. Likewise, the transformational patterns of action involve the display of behaviors that strengthen and inspire people by giving them the confidence to reach a high level of performance. In this sense Beauchamp, Barling and Morton (2011) found that transformational teaching is associated with cognitive improvements — beliefs, attitudes and motivation-, emotionals - fun, satisfaction - , and behavioral - effort made - during Physical Education classes and PA practice in young adolescents.

Some methodological issues with regard to the present study should be considered. One limitation of this study is that the recorded measures come from the children and adolescents. Future research should obtain information from the parents in relation to their own parental style. In addition, the study design is cross-sectional, making impossible to establish causal relationships or directionality among the analyzed variables. However, BMI and fitness measures have been carried out using validated and reliable field tests and psychological well-being using established measures.

It is concluded that in girls, age and the perception of a maternal and paternal transformational style, predict the subjective happiness, psychological wellbeing, and distress independently of physical fitness level. In boys, only the parental transformational style acts as a significant predictor 
independently of age, BMI and physical fitness level. With the exception of explosive strength in girls, neither speedagility nor cardiorespiratory capacity, contribute to explain the subjective well-being in adolescents. Our findings suggest promoting parenting transformational styles, above all in younger adolescents aged 12-16 years. In girls, to promote a higher muscular strength, could contribute to improve happiness and wellbeing independently of parental transformational styles. At educational level, PE teacher could add more muscular strength activities during the classes and promote the extracurricular PA programmes of the school. Creating parental training or workshops to encourage parenting transformational style, would be another interesting initiative to raise happiness and wellbeing levels among young people.

\section{References}

Álvarez, O., Castillo, I., Molina-García, V. \& Balagué, G. (2016) Transformational leadership on the athletic field: An international review. Revista de Psicología del Deporte, 25(2), 319-326.

Álvarez, O., Castillo, I. \& Moreno-Pellicer, R. (2019). Transformational parenting style, autonomy support, and their implications for adolescent athletes' burnout. Psychosocial Intervention, 28(2), 91-100. doi:10.5093/pi2019a7

Arthur, C. A., Woodman, T., Ong, C. W., Hardy, L. \& Ntoumanis, N. (2011). The role of athlete narcissism in moderating the relationship between coaches' transformational leader behaviors and athlete motivation. Journal of Sport \& Exercise Psychology, 33(1), 3-19.

Beauchamp, M. R., Barling, J. \& Morton, K. L. (2011). Transformational teaching and adolescent self-determined motivation, self-efficacy, and intentions to engage in leisure time physical activity: A randomized controlled pilot trial. Applied Psychology: Health and Well-Being, 3(2), 127-150. doi:10.1111/ j.1758-0854.2011.01048.x.

Bonhauser, M., Fernández, G., Püschel, K., Yáñez, F., Montero, J., Thompson, B. \& Coronado G. (2005). Improving physical fitness and emotional well-being in adolescents of low socioeconomic status in Chile: Results of a school-based controlled trial. Health Promotion International, 20(2), 112-122. doi:10.1093/heapro/ dah603

Bono, J. E. \& Ilies, R. (2006). Charisma, positive emotions and mood contagion. The Leadership Quarterly, 17(4), 317-334. doi:10.1016/j.leaqua.2006.04.008

Boros, P., Fontana, F. \& Mack, M. (2017). A comparison of physical activity engagement and enjoyment in female college students with and without a history of weight-related teasing. College Student Journal, 51(3), 444-452.

Bourne, J., Liu, Y., Shields, C. A., Jackson, B., Zumbo, B. Z. \& Beauchamp, M. R. (2015). The relationship between teaching and adolescent physical activity: The mediational roles of personal and relational efficacy beliefs. Journal of Health Psychology, 20(2), 132-143. doi:10.1177/1359105313500096

De la Torre-Cruz, M. J., Ruiz-Ariza, A., López-Serrano, S. \& MartínezLópez, E. J. (2018). La parentalidad transformacional se relaciona positivamente con el autoconcepto físico de jóvenes adolescentes. Retos, 34, 3-7.

Heubeck B. G. \& Neill, J. T. (2000). Confirmatory factor analysis and reliability of the Mental Health Inventory for Australian adolescents. Psychological Reports, 87(2), 431-440. doi:10.2466/ pr0.2000.87.2.431

Ho, F. K. W., Louie, L. H. T., Chow, C. B., Wong, W. H. S. \& Ip, P. (2015). Physical activity improves mental health through resilience in Hong Kong Chinese adolescents. BMC Pediatrics, 15(48). doi:10.101186/s12887-015-0365-0

Huffman, L. E., Wilson, D. K., Van Horn, M. L. \& Pate, R. R. (2018). Associations between parenting factors, motivation, and physical activity in overweight African American adolescents.
Annual Behavior and Medicine, 52(2), 93-105. doi:10.1007/ 212160-017-9919-8

Jiménez-Moral, J. A., Zagalaz-Sánchez, M. L., Molero, D., PulidoMartos, M. \& Ruiz, J. (2013). Capacidad aeróbica, felicidad y satisfacción con la vida en adolescentes españoles. Revista de Psicología del Deporte, 22(2), 429-436.

Kim, H. H. (2016). The impact of online social networking on adolescent psychological well-being (WB): a population-level analysis of Korean school-aged children. International Journal of Adolescence and Youth. doi:10.1080/ 02673843.2016 .1197135

Léger, L. A., Mercier, D., Gadour, C. \& Lambert, J. (1988). The multistage 20 metre shuttle run test for aerobic fitness. Journal of Sports Science, 6(2), 93-101. doi:10.1080/ 02640418808729800

Lim, S. A., You, S. \& Ha, D. (2015). Parental emotional support and adolescent happiness: Mediating roles of self-esteem and emotional intelligence. Applied Research Quality Life, 10(4), 631-646.

Lyubomirsky S. \& Lepper H. S. (1999). A measure of subjective happiness: Preliminary reliability and construct validation. Social Indicators Research, 46(2), 137-55.

McMahon, E. M., Corcoran, P., O’Regan, G., Keeley, H., Cannon, M., Carli, V., ... Wasserman, D. (2017). Physical activity in European adolescents and associations with anxiety, depression and well-being. European Children and Adolescents Psychiatry, 26(1), 111-122. doi:10-10007/s00787-016-0875-9

Moreira, P. A. S., Cloninger, C. R., Dinis, L., Sá, L., Oliveira, J. T., Dias, A. \& Oliveria, J. (2015). Personality and well-being in adolescents. Frontiers in Psychology, 5:1494. doi:10.3389/ fpsyg.2014.01494

Morton, K. L., Barling, J., Rhodes, R. E., Mâsse, L. C., Zumbo, B. D. \& Bauchamp, M. R. (2011). The application of transformational leadership theory to parenting: Questionnaire development and implications for adolescent self-regulatory efficacy and life satisfaction. Journal of Sport \& Exercise Psychology, 33(5), 688-709.

Morton, K. L., Wilson, A. H., Perlmutter, L. S. \& Beauchamp, M. R. (2012). Family leadership styles and adolescent dietary and physical activity behaviors: A cross-sectional study. International Journal of Behavioral Nutrition and Physical Activity, 9(48). doi:10.1186/1479-5868-9-48

Popper, M. \& Mayseless, O. (2003). Back to basics: Applying parenting perspective to transformational leadership. Leadership Quarterly, 14(1), 41-65. doi:10.1016/S1048-9843(02)00183-2

Ruiz, J. R., Castro-Pinero, J., España-Romero, V., Artero, E. G., Ortega, F. B., Cuenca, M. M., ... Castillo, M. J. (2011). Field-based fitness assessment in young people: the ALPHA health-related fitness test battery for children and adolescents. British Journal of Sports Medicine, 45(6), 518-524. doi:10.1136/ bjsm.2010.075341

Skakon, J., Nielsen, K., Borg, V. \& Guzman, J. (2010). Are leaders' well-being, behaviours and style associated with the affective well-being of their employees? A systematic review of three decades of research. Work \& Stress, 24(2) 107-139. doi:10.1080/ 02678373.2010 .495262

Smith, J. J., Eather, N., Morgan, P. J., Plotnikoff, R. C., Fagenbaum, A. D. \& Lubans, D. R. (2014). The health benefits of muscular fitness for children and adolescents: A systematic review and meta-analysis. Sports Medicine, 44(9), 1209-1233. doi:10.1007/ s40279-014-0196-4

Stenling, A. \& Tafvelin, S. (2014). Transformational leadership and well-being in sports: The mediating role of need satisfaction. Journal of Applied Sport Psychology, 26(2), 182-196, doi: 10.1080/10413200.2013.819392

Veit, C. T. \& Ware, J. (1983). The structure of psychological distress and well-being in general populations. Journal of Consulting and Clinical Psychology, 51(5), 730-742.

Verma, N., Eklund, R. C., Arthur, C. A., Howle, T. C. \& Gibson, A. (2019). Transformational teaching, self-presentation motives, and identity in adolescent female physical education. Journal of Sport and Exercise Psychology, 41(1), 1-9 doi:10.1123/jsep.20170299 